\title{
РОЛЬ ВІРТУАЛЬНИХ ТЕХНОЛОГІЙ В ЯКОСТІ ПРОФЕСІЙНОЇ ПІДГОТОВКИ МЕДИЧНИХ ПРАЦВНИКІВ
}

\author{
I. A. Анчева
}

\author{
Одеський начіональний медичний університет
}

\section{ROLE OF MODERN VIRTUAL SIMULATORS FOR VOCATIONAL TRAINING OF MEDICAL PROFESSIONS}

\section{A. Ancheva}

\author{
Odesa National Medical University
}

\begin{abstract}
Визначена роль і необхідність у використанні сучасних віртуальних симуляторів, що забезпечують створення реальності медичних втручань і процедур, в курсі освоєння клінічних дисциплін і для вдосконалення практичних навиків. На сьогодні робота на фантомах є перехідним рівнем від теорії до практичної діяльності лікаря.

There is determine the role and the necessity to use modern virtual simulators that provide a reality of medical interventions and procedures in the course of development of clinical disciplines and improve practical skills. In the modern days training on phantoms is a transitional level for the movement from theory to medical practice.
\end{abstract}

Вступ. Лікар належить до однієї з найдревніших, найбільш відповідальних професій, що затребувані у наш час. У червні 1999 р. в Болоньї (Італія) була підписана декларація, названа згодом Болонською. Вона передбачає створення загальноєвропейського простору вищої освіти. У 2011 році в Україні відбувся перший випуск фахівців з вищою медичною освітою, які вчилися за новою навчальною програмою, підготовленою з врахуванням вимог Європейської кредитномодульної системи (European Credit Transfer System).

У процесі вивчення клінічних дисциплін навчальною програмою передбачена курація хворих під час практичних занять, з подальшим написанням історій хвороб. Під час написання історії хвороби студент отримує досвід спілкування з пацієнтом, застосовує вивчені на фантомі практичні навики огляду пацієнта, знайомиться з медичною документацією і режимом роботи клінік. У процесі навчання студенти набувають професійних знань і навиків, вдосконалення яких триває все життя [4].

Основна частина. Згідно 3 новими вимогами були внесені зміни в навчальні плани з усіх дисциплін. На лекціях і практичних заняттях викладачами кафедри широко використовуються мультимедійні презентації, демонструються відеофільми. Для методичного забезпечення навчального процесу співробітниками ка-

(ㄱ I. А. Анчева федри постійно оновлюються навчально-методичні посібники. У навчальний процес залучено так само тестування, кредитно-модульну систему, дистанційний метод навчання, незалежну систему експертної оцінки знань студентів, і передбачений час для самостійної та індивідуальної роботи студентів $[1,6]$.

Дана система передбачає впровадження сучасних технічних і інформаційних досягнень, з урахуванням підвищення вимог до підготовки висококваліфікованих фахівців в різних галузях. Глибокі традиції вітчизняної медицини-це всього лише основа подальшого ії розвитку. Можливість вчитися біля ліжка реального хворого, з точки зору підготовки висококваліфікованої лікарки, залишається найбільш вартісною і в наші дні.

Принципи деонтології обмежують взаємодію студентів 3 пацієнтами в навчальному процесі, оскільки при навчанні можуть бути зачеплені персональні інтереси пацієнта, втручання в його особисте життя. "Не нашкодь" (лат. "Noli nocere") - головна заповідь лікаря, сформульована ще знаменитим старогрецьким лікарем Гіппократом [2, 5].

Можливість удосконалення практичних навиків для студентів медичних вузів особливо важлива зараз, коли відбуваються процеси реформування і модернізації галузі, а також з підвищенням вимог до підготовки лікарів-курсантів. Зараз від лікаря-фахівця після закінчення навчання потрібно не лише уміти огляну- 
ти пацієнта, але і надати йому будь-яку лікувальнодіагностичну допомогу в повному об'ємі залежно від конкретної ситуації [8].

Загальновідомо, що засвоїти ряд клінічних дисциплін неможливо без занять на фантомі, які дають можливість поступово перейти від вивчення теоретичних питань до практичної діяльності лікаря. Методики навчання на фантомах у медицині відомі вже давно, зокрема в акушерстві і гінекології Н. М. Максимович-Амбодик створив модель акушерського фантома в 1782 р.

Викладання “бабичого дела" супроводжувалося демонстраціями фантома жіночого таза і ряду акушерських інструментів (акушерські щипці, срібний жіночий сечовий катетер), які були виготовлені за його власними моделями і малюнками [9, 10].

Удосконалення навчального процесу стало можливим з розвитком техніки - деякі професійні уміння лікарі можуть відпрацьовувати заздалегідь на тренажерах. Організація сучасного фантомного навчання, на додаток до традиційних занять на кафедрах медичного університету, в сукупності з проходженням практики в університетських клініках, є на сьогодні ефективним методом підвищення якості медичної освіти у майбутніх лікарів будь-якої спеціальності [11].

Сучасні тренажери, оснащені електронною апаратурою, дозволяють моделювати не лише прості мануальні дії, але й імітувати різні симптоми (крик дитяти, шуми серця і легенів, наявність пухлин і кровотеч у різних органах тощо). Вони демонструють прояви патологічних станів, що вимагають екстрених дій бригади лікарів з надання комплексної лікарської допомоги, моделюють зміни стану пацієнта після проведених лікувальних заходів. Фантомні багатофункціональні системи, що імітують складні клінічні ситуації і стани пацієнта, - це фантоми-манекени таких напрямів, як: акушерсько-гінекологічний, хірургічний, травматологічний, терапевтичний, стоматологічний, невідкладних станів (реанімаційний) і інші спеціалізації [3].

Симуляційне навчання в медичній освіті вирішує такі завдання:

1. Сучасні тренажери дозволяють змоделювати безліч різних ситуацій, з якими лікарки стикаються в реальній практиці.

2. Максимально наближають виконувані маніпуляції до реальної професійної діяльності.

3. Дозволяють поетапно відпрацьовувати будь-які практичні навики.

4. Дають можливість повторення будь-якого практичного навику необмежену кількість разів при за- безпеченні своєчасних, детальних професійних інструкцій у ході роботи.

5. Створюють умови для вироблення і підтримки навиків і професійних дій у рідких ситуаціях, необхідних кожній практикуючій лікарці.

6. Систематизують знання з клінічних дисциплін.

7. Надають можливість аналізувати і вчитися на власних помилках, без шкоди для здоров'я пацієнта.

8. Підвищують швидкість навчання у декілька разів за рахунок швидшого закріплення мануальних навиків, незалежно від роботи клініки.

9. Допомагають відпрацьовувати навики без стресу для того, хто навчається.

10. Нові технології допоможуть різко понизити число лікарських помилок.

Хірургічна діяльність у роботі лікаря акушерагінеколога є складною і невід'ємною частиною, що визначає кваліфікацію фахівця. Лікар акушер-гінеколог, що працює в стаціонарі, зобов'язаний надавати планову і ургентну хірургічну допомогу. Хірург має бути підготовлений до роботи теоретично, психологічно, зберігати упевненість в будь-якій екстремальній ситуації, постійно удосконалювати хірургічну майстерність.

Теоретична підготовка лікаря у поєднанні з хірургічними навиками визначають кваліфікацію лікаря. Проте відпрацювання практичних навиків виконання операцій, шляхи розширення арсеналу хірургічних прийомів для лікаря залишаються важко вирішуваними питаннями в системі післядипломного навчання. Знайомство лікаря з гінекологічними операціями зазвичай починається з читання підручників з оперативної гінекології, з вивчення малюнків і таблиць, з роботи в анатомічному залі.

Наступними етапами $є$ : перегляд операцій, участь в асистенціях і потім "самостійна" робота в операційній під керівництвом досвідченого колеги. Такий шлях проходить більшість починаючих лікарів. Не заперечуючи важливості кожного $з$ перерахованих етапів у становленні хірурга, слід підкреслити, що при вивченні книг, малюнків неможливо з' ясувати багато деталей і особливості техніки операцій.

Сучасні підручники з оперативної техніки описують один, рідко два варіанти поширених операцій. Практично ніде не даються рекомендації щодо техніки виконання окремих етапів, не відбивається роль помічників хірурга. Наступні етапи - перегляд операцій і асистенції також виключають самостійне напрацювання навіть таких елементарних прийомів, як розтин тканин, ушивання, накладення затисків тощо.

I, нарешті, найбільш відповідальний етап у становленні хірурга-самостійне проведення операції почи- 
нається за відсутності хірургічних навиків. Складність цього етапу визначається ще тим, що будь-який лікар, навіть досвідчений, відчуває хвилювання перед операцією. Тому навчання під час безпосередньої роботи в операційній неповноцінне, займає триваліший час, а головне, нерідко в збиток пацієнту [7].

Таким чином, на етапі становлення хірурга починаючий лікар зустрічається з великими труднощами. Це зумовлює необхідність у створенні симуляційних центрів, які дозволять полегшити неминучі складнощі в освоєнні хірургічної техніки без збитку для здоров' я пацієнта. В ході роботи з фантомом учні освоюють зав' язування різних вузлів ручним і інструментальним способами. Опрацювання практичних навиків на фантомі, наприклад в акушерстві, сприяє розвитку в учнів “м' язового відчуття”, яке визначає силу тракцій при акушерській допомозі. Основна мета застосування віртуально-реальних тренажерних систем у тому, що відбувається формування психомоторних навиків.

\section{Література}

1. Анализ функционирования центров моделирования в системе подготовки медицинских кадров / Л. Б. Шубина, Д. Н. Грибков, В. А. Аверьянов, В. А. Жирнов // Виртуальные технологии в медицине. - 2012. - № 2. - С. 7-12.

2. Блохин Б. М. Симуляционное обучение навыкам работе в команде / Б. М. Блохин, И. В. Гаврютина, Е. Ю. Овчаренко // Виртуальные технологии в медицине. - 2012. № 1 (7). - С. 18-20.

3. Горшков М. Д. Классификация симуляционного оборудования / М. Д. Горшков, А. В. Федоров // Виртуальные технологии в медицине. -2012. - № 2 (8), - С. 21-30.

4. Ласитчук О. М. Написання історії пологів як один із видів самостійної роботи студентів / О. М. Ласитчук // Медична освіта. -2013. - № 3.- С. 51-54.

5. Муравьев К. А. Симуляционное обучение в медицинском образовании - переломный момент / К. А. Муравьев, А. Б. Ходжаян, С. В. Рой // Фундаментальные исследования. - М., 2011. - № 10 (часть 3). - С. 534-537.

6. Мурин С. Использование симуляторов в обучении: переломный момент / С. Мурин, С. Столленверк // Виртуальные технологии в медицине. -2011. - № 1(5). - С. 7-10.
Лише за допомогою високотехнологічних, сучасних симуляційних тренажерів, що максимально наближені до людини й імітують різні прояви патології, починаючий лікар може набути, розвинути і удосконалити хірургічну майстерність.

Висновки. Таким чином, на сьогодні підготовка кваліфікованих медичних фахівців має комплексний підхід із застосуванням різних віртуальних технологій. На сьогодні сучасні методики використовуються в організації навчання при різних клінічних ситуаціях, $\mathrm{i}$ активізують пізнавальну діяльність учнів.

Симуляційні методики, в тому числі з належним програмним забезпеченням для максимальної індивідуалізації програм навчання, мають бути використані при підготовці у вищих медичних школах на різних курсах навчання студентів, а також на етапі післядипломної освіти.

Система хірургічного моделювання є одним з перспективних напрямів у сфері поліпшення процесу навчання, сприяє швидкому освоєнню оперативної техніки, осмисленню ряду хірургічних маніпуляцій.

7. Підвищення якості навчання практичним навичкам у післядипломній медичній освіті з використанням муляжів та тренінгових класів / О. М. Хвисюк, В. Г. Марченко, В. В. Жеребкін [та ін.] // Медична освіта. - 2012. - № 2. C. 72-74.

8. Совцов С. А. Симуляционные технологии в подготовке молодых хирургов / С. А. Совцов, Р. 3. Газизуллин // Виртуальные технологии в медицине. -2013. - № 2 (10). C. 6-9.

9. Simulation-based objective assessment discerns clinical proficiency in central line placement a construct validation / Y. Dong, H. S. Suri, D. A. Cook [et al.] // Chest. - 2010. Vol. 137 (5), №6. - P. 1050-1056.

10. Features and uses of high-fidelity medical simulations that lead to effective learning: a BEME systematic review / S. B. Issenberg, W. C. McGaghie, E. R. Petrusa [et al.] // Med. Teach. -2005. - Vol. 27(1), № 6. - P. 10-28.

11. A prospective multicenter study of competency metrics and educational interventions in the learning of bronhoscopy among new pulmonary fellows / M. M. Wahidi, G.A. Silvestri, R. D. Coakle [et al.] // Chest. - 2010. - Vol. 137 (5), № 6. P. 1040-1049. 